\title{
EFEKTIVITAS METODE BERCERITA DENGAN BUKU CERITA BERGAMBAR BERBASIS ISLAM DALAM MEMBINA AKHLAK SISWA SDIT BUNAYYA PADANGSIDIMPUAN
}

\author{
NURSYAIDAH \\ Lecturer of Tarbiyah and Techer Training Faculty at IAIN Padangsidimpuan \\ Jl. T. Rizal Nurdin Km. 4.5 Sihitang Padangsidimpuan 22733 \\ Email: syaidahiainpsp@yahoo.co.id
}

\begin{abstract}
Attitude is the most important aspect in human life because it relates to all the action and human character like good character or bad character with Allah and human. Attitude is one of the three basic from Islam religion and also has important position. So using the telling the story in Islam method can improve the students' attitude. Formulation of this research is how is the learning process done by using telling stories method of Islamic pictured book in teaching attitude of students in SDIT Bunayya Padangsidimpuan? How effective of telling stories method with Islamic picture book in teaching attitude for students in SDIT Bunayya Padangsidimpuan? The result of research in learning process use telling stories method of Islamic pictured book in teaching attitude of students in SDIT Bunayya Padangsidimpuan with values of religion by the aims can teaching the students' attitude. Actually, telling stories method of Islamic pictured book can teach the students' attitude because by telling the story method, the students can understand what the teacher said.
\end{abstract}

Keywords: telling stories method, Islamic pictured, Students attitudes.

\begin{abstract}
Abstrak
Akhlak merupakan hal yang terpenting dalam kehidupan manusia karena akhlak sudah mencakup segala pengertian tingkah laku, tabi'at, perangai dan karakter manusia yang baik maupun yang buruk dalam hubungannya dengan Rabb-nya atau dengan sesama makhluk-Nya. Akhlak salah satu dari tiga kerangka dasar ajaran Islam juga memiliki kedudukan yang sangat penting. Sehingga dengan penerapan metode bercerita bergambar Islam diharapkan dapat meningkat akhlak siswa. Rumusan masalah dalam penelitian ini adalah Bagaimana proses pembelajaran menggunakan metode bercerita dengan buku cerita bergambar berbasis Islam dalam membina akhlak siswa SDIT Bunayya Padangsidimpuan? Bagaimana efektifitas metode bercerita dengan buku cerita bergambar berbasis Islam dalam membina akhlak siswa SDIT Bunayya Padangsidimpuan? Hasil penelitian Proses pembelajaran menggunakan metode bercerita dengan buku cerita bergambar berbasis Islam dalam membina akhlak siswa SDIT Bunayya Padangsidimpuan dengan penanaman nilai-nilai agama dengan tujuan agar dapat membina akhlak siswa. Ternyata dengan menggunakan metode bercerita dapat membina akhlak siswa karena dengan bercerita siswa dapat memahami apa yang disampaikan oleh guru.
\end{abstract}

Kata Kunci : Efektifitas, Metode cerita, Gambar Islami, Akhlak Siswa 


\section{PENDAHULUAN}

Dalam kehidupan manusia tidak akan terlepas dari apa yang disebut pendidikan. Pendidikan adalah usaha sadar dan terencana untuk mewujudkan suasana belajar dan proses pembelajaran agar peserta didik secara aktif mengembangkan potensi dirinya untuk memiliki kekuatan spiritual keagamaan, pengendalian diri, kepribadian, kecerdasan akhlak mulia, serta keterampilan yang diperlukan dirinya, masyarakat, bangsa dan Negara. ${ }^{1}$ Dengan demikian, pendidikan memegang peranan penting dalam menentukan hitam putihnya manusia, dan akhlak juga jadi standar kualitas manusia, artinya baik buruknya akhlak salah satu indikator berhasil tidaknya pendidikan.

Tujuan tersebut selaras dengan tujuan pembangunan nasional, sehubungan dengan itu pula pasal 36 dan 37 undang-undang tersebut mengatakan agar kurikulum disusun antara lain dengan memperhatikan peningkatan iman dan taqwa dan akhlak mulia terutama untuk pendidikan Sekolah Dasar. ${ }^{2}$

Metode cerita mengandung arti suatu cara dalam menyampaikan materi pelajaran dengan menuturkan secara kronologis tentang bagaimana terjadinya sesuatu hal baik yang sebenarnya terjadi ataupun hanya rekaan saja. Metode kisah merupakan salah satu metode yang mashur dan terbaik, sebab kisah ini mampu menyentuh jiwa jika didasarkan oleh ketulusan hati yang mendalam ${ }^{3}$. Kisah atau cerita sebagai suatu metode pendidikan ternyata mempunyai daya tarik yang menyentuh perasaan. Islam menyadari sifat alamiah manusia untuk menyenangi cerita itu, dan menyadari pengaruhnya yang besar terhadap perasaan. Oleh karena itu Islam mengekploitasi cerita tersebut untuk dijadikan salah satu metode pendidikan.

Metode bercerita bergambar adalah salah satu cara untuk membentuk akhlak mulia seorang anak. Dimana dalam metode ini, setiap buku agama Islam yang menceritakan kisahkisah nabi maupun kisah teladan lainnya disajikan dalam bentuk bergambar. Dengan melihat gambar-gambar tersebut, maka seorang anak ketika membaca kisah-kisah itu dapat menarik intuisinya untuk meniru gambar-gambar tersebut dan respon siswapun akan positif terhadap gambar. Sehingga secara tidak langsung akhlak tersebut telah tertanam pada diri anak.

Akhlak merupakan hal yang terpenting dalam kehidupan manusia karena akhlak sudah mencakup segala pengertian tingkah laku, tabi'at, perangai dan karakter manusia yang baik maupun yang buruk dalam hubungannya dengan Rabb-nya atau dengan sesama makhluk-Nya. Akhlak salah satu dari tiga kerangka dasar ajaran Islam juga memiliki kedudukan yang sangat penting. Akhlak merupakan buah yang dihasilkan dari proses

\footnotetext{
${ }^{1}$ Departemen Pendidikan Nasional, Undang-Undang Sistem Pendidikan Nasional Nomor 20 Tahun 2003, (Jakarta: Departemen Pendidikan Nasional, 2003), hlm. 6.

2 Depdiknas, Undang-undang tentang Perencanaan Pembangunan Nasional No.25, tahun 2004, (Jakarta: Depdiknas, 2004), hlm. 13.

${ }^{3}$ Armai Arief, Pengantar Ilmu dan Metodologi Pendidikan Islam, (Jakarta: Ciputat Pers, 2002), hlm. 160 .
} 
menerapkan aqidah dan syariah. Ibarat bangunan, akhlak merupakan kesempurnaan dari bangunan tersebut setelah fondasi dan bangunannya kuat. Jadi, tidak mungkin akhlak ini akan terwujud pada diri seseorang jika dia tidak memiliki aqidah dan syariah yang baik.

Observasi awal di SDIT Bunayya menunjukkan bahwa sekolah ini merupakan salah satu sekolah yang menerapkan proses pembelajaran terpadu. Adapun visi SDIT ini adalah untuk menciptakan akhlak dalam proses pembelajaran yang Islami. Berdasarkan visi SDIT Bunayya tersebut guru dituntut untuk menggunakan salah satu metode yakni dengan metode bercerita karena dengan metode ini siswa dianggap mampu membina akhlak siswa.

Berdasarkan observasi awal peneliti juga melihat bahwasanya metode bercerita yang digunakan guru di SDIT Bunayya cukup efektif dalam membina akhlak siswa. Akan tetapi, aplikasi yang ditunjukkan oleh sebagian siswa dalam sikap sehari-harinya belum terlihat dari tingkah lakunya. Misalnya, siswa masih mau berkata yang kurang sopan terhadap gurunya dan sesama temannya.

Berdasarkan jabaran di atas, dapat dipahami bahwa metode bercerita melalui gambar dapat membentuk watak dan sifat siswa atau akhlak mulia siswa. Hal ini mendorong penulis untuk mengadakan penelitian tentang “Efektivitas Metode Bercerita Dengan Buku Cerita Bergambar Berbasis Islam Dalam Membina Akhlak Siswa SD IT Bunayya Padangsidimpuan".

Selanjutnya, berdasarkan latar belakang masalah di atas, maka yang menjadi fokus masalah dalam penelitian ini adalah efektivitas metode bercerita dengan buku cerita bergambar berbasis Islam dalam membina akhlak siswa SD IT Bunayya Padangsidimpuan. Adapun rumusan masalah dalam penelitian ini adalah:

1. Bagaimana proses pembelajaran menggunakan metode bercerita dengan buku cerita bergambar berbasis Islam dalam membina akhlak siswa SDIT Bunayya Padangsidimpuan?

2. Bagaimana efektifitas metode bercerita dengan buku cerita bergambar berbasis Islam dalam membina akhlak siswa SDIT Bunayya Padangsidimpuan?

3. Apa saja kendala yang dihadapi guru dalam membina akhlak siswa di SDIT Bunayya?

\section{TINJAUAN PUSTAKA}

\section{Metode Bercerita}

Secara kebahasaan kata "metode" berasal dari bahasa Yunani yaitu methodos, dan dalam bahasa Inggris ditulis method yang berarti cara atau jalan. Dalam bahasa Arab disebut tariqoh, dan adakalanya disebut uslub. ${ }^{4}$ Dalam kamus besar Bahasa Indonesia metode

\footnotetext{
${ }^{4}$ Hans Wehr, A Dictionary of Modern Written Arabic, (London: Macdonald \& Evans Ltd., 1974), hlm. 420 dan 559; dan juga Muhammad Ali al-Khuli, Dictionary of Education: English Arabic, (Bairut-Libanon: Dar al'Ilm Li al-Malayin, 1981), hlm. 296 dan 297.
} 
adalah cara kerja yang bersistem untuk memudahkan pelaksanaan kegiatan guna mencapai apa yang telah ditentukan. ${ }^{5}$

Sedangkan cerita merupakan suatu bentuk karya sastra yang memiliki keindahan dan kenikmatan tersendiri dan akan memberikan pengaruh baik bagi anak-anak maupun orang dewasa karena dapat mengasah akal dan rasa. Cerita adalah salah satu bentuk sastra yang bisa dibaca atau hanya didengar oleh orang yang tidak bisa membaca. Dalam kamus besar Bahasa Indonesia cerita adalah karangan yang menuturkan perbuatan, pengalaman atau penderitaan orang, kejadian dan sebagainya (baik yang sungguhsungguh terjadi maupun hanya rekaan belaka). ${ }^{6}$

Pemilihan metode pembelajaran yang tepat sangat menentukan sebuah pembelajaran. Metode dipilih dalam rangka mencapai tujuan pembelajaran. Metode yang dipilih oleh pendidik tidak boleh bertentangan dengan tujuan pembelajaran. Metode harus mendukung kemana kegiatan interaksi edukatif berproses guna mencapai tujuan. Tujuan pokok pembelajaran adalah mengembangkan kemampuan anak secara individu agar bisa menyelesaikan segala permasalahan yang dihadapinya. Metode pembelajaran yang biasa diterapkan di SD ada beberapa macam salah satunya adalah metode bercerita.

Menurut beberapa pengertian di atas metode bercerita yaitu suatu cara memberikan pengalaman belajar yang bermacam-macam pada siswa serta memberikan pengalaman psikologis dan linguistik pada siswa secara lisan untuk mengajarkan atau menyampaikan pesan-pesan moral bagi siswa. Berdasarkan jabaran terseebut di atas, metode bercerita adalah salah satu pemberian pengalaman belajar bagi anak SD dengan membawakan cerita kepada anak secara lisan.

Cerita bagi anak memiliki manfaat yang sama pentingnya dengan aktivitas dan program itu sendiri. Ditinjau dari berbagai aspek manfaat cerita bagi anak yaitu: ${ }^{7}$

1) Membantu pembentukan watak kepribadian dan moral anak.

2) Menyalurkan kebutuhan imajinasi dan fantasi anak.

3) Memacu kemampuan verbal atau berbahasa anak.

4) Merangsang minat menulis anak.

5) Merangsang minat membaca bagi anak.

6) Membuka cakrawala pengetahuan anak atau menambah pengetahuan anak.

Berdasarkan uraian di atas metode bercerita sangat efektif diterapkan di lembaga pendidikan SD, mengingat anak usia SD merupakan masa peka dimana anak mulai sensitif untuk menerima berbagai upaya pengembangan seluruh potensi anak. Masa ini merupakan masa untuk meletakkan dasar pertama dalam mengembangkan kemampuan fisik, kognitif, bahasa, sosial emosional, disiplin, moral, dan nilai-nilai agama. Dengan

${ }^{5}$ Departeman Pendidikan Nasional, Kamus Besar Bahasa Indonesia (Jakarta: Depdiknas, 2011), hlm. 910.

\footnotetext{
${ }^{6}$ Op.cit., hlm. 263

${ }^{7}$ Loc.cit., hlm. 81 .
} 
menggunakan metode bercerita guru bisa menyampaikan materi pembelajaran pendidikan agama Islam, kemandirian maupun akhlak perilaku terpuji dengan suasana yang menyenangkan dan menarik bagi anak. Dengan suasana yang menyenangkan materi pendidikan agama Islam yang diajarkan akan mudah diterima.

\section{Metode Kisah}

Dalam proses pembelajaran metode kisah sangat digemari oleh anak didik, kedudukan metode kisah sangat penting sebagai metode yang juga berpengaruh terhadap proses belajar mengajar. Hal ini oleh beberapa factor, yaitu (1) metode kisah selalu memikathati dan mengundang pembaca atau pendengar untuk mengikuti peritiwanya dan merenungkan maknanya, sehingga timbul kesan di dalam jiwa, (2) metode kisah dapat menyentuh hati manusia, sebab kisah biasanya menyentuh kehidupan yang menyeluruh yang ditampilkan tokoh sentral dalam kisah itu, (3) kisah Qur'ani mendidik perasaan keimanan dengan cara membangkitan perasaan takut, ridha dan cinta, melibatkan emosional keagamaan pendengar ke dalam kisah tersebut.

\section{Metode Keteladanan}

Metode keteladanan adalah suatu cara penyampaian materi dengan terlebih dahulu guru melaksanakannya yang kemudian siswa mengikutinya secara kontiniu dan berkesinambungan. Metode ini tidak banyak tuturan lisan dari seorang guru, akan tetapi menuntut pada implimintasi pada perbuatan guru itu sendiri yang akhirnya ditiru oleh peserta didik.

Mendidik dengan memberi contoh adalah salah satu cara yang contoh yang paling banyak meninggalkan pesan. Carilah sosok figur yang memeliki nilai-nilai yang ingin kita ajarkan di tengah-tengah siswa. Teladan itu seperti magnet yang menyedot siswa untuk mengikuti apa yang mereka lihat dengan kepala mata sendiri. Tidak ada yang meragukan betapa efeknya teladan itu karena disetiap jiwa tersimpan semangat seperti itu. ${ }^{8}$

Metode keteladanan ini memang berpusat pada pendidik. Keteladanan personal para pendidik merupakan kunci keberhasilan dalam menerapkan metode ini. Betapapun metode pembiasaan memang efektif untuk pembentukan sikap dan nilai-nilai, akan tetapi jika tidak diimbangi dengan keteladanan para pendidiknya maka hasilnyapun, jika tidak sia-sia sama sekali maka sekurang-kurangnya menjadi kurang efektif. Itulah sebabnya keteladanan pendidik merupakan prasyarat bagi keberhasilan pendidikan. ${ }^{9}$

\section{Metode Pembiasaan}

Dalam pembentukan sikap, metode pembiasaan sebenarnya cukup efektif, orang yang terbiasa bersih akan memilih hidup bersih, tidak saja bersih fisik, tetapi bisa berdampak

\footnotetext{
${ }^{8}$ Iistarani, Kumpulan 39 Metode Pembelajaran (Medan: Cv Iscom Medan, 2012), hlm.142.

${ }^{9}$ Jamil Suprihatiningrum, strategi pembelajaran (yogyakarta: ar-Ruzz Media, 2013) hlm.267.
} 
terhadap bersih pikiran dan hatinya. Perlu diingat bahwa, pembiasaan berintikan pengulangan, maka metode pembiasan juga berguna untuk menguatkan ingatan. ${ }^{10}$

\section{Buku Bergambar Berbasis Islam}

Bercerita merupakan kegiatan menyampaikan amanat atau pesan melalui sejumlah kata-kata, dengan cara yang menarik melalui media atau nonmedia oleh pencerita kepada pendengar sehingga pesan yang dimaksudkan dapat dimengerti. Salah satu media yang memacu masuknya pesan yang disampaikan oleh pencerita adalah buku bergambar berbasis islam, dengan adanya media akan mempermudah materi sampai kepada anak karena proses pengajaran tidak membosankan dimana media pengajaran dapat mempertinggi proses belajar siswa, sebab:

1) Pengajaran akan lebih menarik perhatian siswa sehingga dapat menumbuhkan motivasi belajar.

2) Bahan pengajaran akan lebih jelas maknanya sehingga dapat lebih dipahami oleh para siswa, dan memungkinkan siswa menguasai tujuan pengajaran lebih baik.

3) Metode mengajar akan lebih bervariasi, tidak semata-mata komunikasi verbal melalui penuturan kata-kata oleh guru, sehingga siswa tidak bosan dan guru tidak kehabisan tenaga, apalagi bila guru mengajar untuk setiap jam pelajaran.

4) Siswa lebih banyak melakukan kegiatan belajar, sebab tidak hanya mendengarkan uraian guru, tetapi juga aktivitas lain seperti mengamati, melakukan, mendemonstrasikan dan Iain-lain.

Bercerita menggunakan buku cerita bergambar merupakan satu teknik yang dapat dilakukan guru untuk mendidik akhlak anak, dimana ketika guru memberikan stimulus berupa metode bercerita melalui buku gambar berbasis islam, maka respon yang diharapkan berupa akhlak siswa akan membaik. Mealui buku bergambar berbasis islam ini, seorang siswa akan memperhatikan bukunya, dengan perhatian tersebut siswa akan mencoba meniru atau meneladani cerita yang ada pada buku siswa tersebut.

\section{Pengertian Akhlak Siswa}

Secara etimologi, akhlak dapat diartikan "budi pekerti atau kelakuan"11. Kata "akhlak" berasal dari bahasa Arab, jama dari kata khilqun atau khulqun yang berarti perangai, kelakukan, tabiat, watak dasar ${ }^{12}$. Sedangkan Abudin Nata mengartikan akhlak sebagai perbuatan yang dilakukan dengan mendalam dan tanpa pemikiran. Namun perbuatan itu telah mendarah daging dan melekat dalam jiwa, sehingga saat melakukan perbuatan tidak lagi memerlukan pertimbangan dan pemikiran ${ }^{13}$.

\footnotetext{
${ }^{10}$ Syafaruddin, dkk, Ilmu Pendidikan Islam Melejitkan Potensi Budaya Umat, (Jakarta Selatan: Hijri Pustaka Utama, 2006), hlm. 158-1160.

${ }^{11}$ Suharso dan Ana Retnoningsih, Kamus Besar Bahasa Indonesia, (Semarang: Widya Karya, 2009), hlm.23.

${ }_{12}$ Abudin Nata, Akhlak Tasawuf, (Jakarta: PT. Raja Grafindo Persada, 2006), hlm. 2

${ }^{13}$ Ibid., hlm. 5
} 
Ada dua pendekatan untuk mendefenisikan akhlak, yaitu pendekatan liguistik (Kebebasan) dan pendekatan terminologi (Peristilahan). Akhlak berasal dari bahasa arab yakni khuluqun yang artinya budi pekerti, perangai, tingkah laku, tabiat, adat atau kalqun yang berarti kejadian, buatan ciptaan. ${ }^{14}$ Dengan demikian akhlak merupakan suatu budi pekerti, perangai, tabiat, atau sistem perilaku yang dibuat. Namun akhir-akhir ini istilah akhlak lebih didominasi istilah karakter yang sebenarnya memiliki esensi yang sama, yakni sikap dan perilaku seseorang.

Berdasarkan hal di atas, akhlak secara kebebasan bisa baik dan juga buruk, tergantung kepada tata nilai yang dipakai sebagai landasannya. Akhlak yang baik akan mengangkat derajat manusia di tempat yang lebih tinggi dan mulia, sedangkan akhlak yang buruk akan membinasakan seseorang insan atau bahkan ummat manusia. Senang melakukan kekacauan, atau perbuatan tercela merupakan dampak buruk dari perbuatan akhlak.

\section{Akhlak Siswa di SDIT Bunayya Padangsidimpuan}

Akhlak merupakan tujuan tertinggi dari metode pembelajaran bercerita , karena tujuan utama pembelajaran adalah terbentuknya kepribadian muslim yang sesungguhnya. Selain dari itu, akhlak merupakan tata aturan/norma perilaku yang mengatur hubungan manusia dengan Tuhannya, manusia dengan dirinya, guru sesama muslim lainnya. Berdasarkan penelitian peneliti dapat mendeskripsikan akhlak siswa SDIT Bunayya Padangsidimpuan, yaitu sebagai berikut:

1) Akhlak Kepada Allah SWT

a) Mentauhidkan Allah

Yaitu dengan melaksanakan shalat duha. Sesuai hasil wawancara peneliti bahwa siswa/i SDIT Bunayya selalu melaksanakan shalat duha setiap hari.

b) Taqwa

Yaitu melaksanakan shalat berjamaah di mesjid. Shalat berjamaah di mesjid bisa menanamkan persaudaraan yang tinggi, disiplin, dan patuh kepada orangtua. Oleh karena itu guru SDIT Bunayya selalu berusaha agar shalat berjamaah di mesjid dilaksanakan secara rutin pada tiap-tiap kelas.

c) Berdo'a

Yaitu dengan membawa ayat-ayat pendek sebelum dimulai pelajaran.

d) Tunduk dan patuh hanya kepada Allah

Tunduk dan patuh hanya kepada Allah adalah seseorang yang patuh menjalan ketentuan dan hukum-hukum Allah. Berdasarkan hasil obsevasi peneliti di lapangan bahwa siswa SDIT Bunayya patuh kepada Allah dengan berakhlak mulia.

e) Berserah diri kepada Allah

\footnotetext{
${ }^{14}$ Ahmadi, Abu, Dasar-dasar Pendidikan Agama Islam, (Jakarta: Bumi Aksara, 2008), hlm. 198.
} 
Berserah diri kepada Allah adalah sikap pasrah dalam menerima cobaan, mampu meanggung kesusahan dan penderitaan, kemudian menerimanya dengan tenang. Berdasarkan hasil observasi di lapangan bahwa siswa tidak banyak melakukan hal-hal yang tidak disukai oleh guru maupun orangtua.

f) Bersyukur hanya kepada Allah

Bersyukur yang dilakukan oleh siswa SDIT Bunayya Padangsidimpuan adalah memanfaatkan segala bentuk kelebihan (nikmat) yang dimiliki seseorang.

2) Akhlak Siswa Sesama Siswa

Selain menghormati dan menghargai guru pergaulan sesama siswa juga harus diperhatikan, agar tidak terjadinya konflik diantara sesama siswa, seperti : tidak saling mencaci maki, tidak merendahkan siswa yang lain, tidak saling dendam, tidak mengucapkan kata-kata kasar dan lain sebagainya.

a) Sabar

Kegiatan pembinaan sabar adalah melaksanakan tugas yang diberikan guru.

b) Syukur

Kegiatan pembinaan syukur termasuk menerima penjelasan guru.

c) Tawadhu'

Kegiatan pembinaan tawadhu' yaitu bersungguh-sungguh dalam belajar.

d) Benar

Kegiatan pembinaan benar termasuk pergi ke sekolah dengan tepat waktu. Menghargai waktu merupakan kunci keberhasilan dari suatu aktivitas.

e) Iffah (menahan diri dari yang terlarang)

Kegiataan pembinaan iffah ialah tidak menentang guru ketika mengerjakan soal.

f. Hilman (menahan diri dari marah)

Kegiatan pembinaan hilman ia tidak berkelahi dengan teman ketika ada persoalan tugas.

g. Amanah dan jujur

Kegiatan pembinaan amanah dan jujur termasuk tidak meninggalkan sekolah sebelum waktunya.

\section{METODOLOGI PENELITIAN}

Penelitian ini termasuk penelitian deskriptif kualitatif yakni penelitian yang dilakukan dengan mendeskripsikan fenomena-fenomena secara menyeluruh/ komprehensif (mendalam). Jenis Penelitian ini termasuk penelitian riset lapangan (field reseach) yaitu dengan menggunakan informasi yang diperoleh dari sasaran peneitian yang selanjutnya 
disebut informan/ responden melalui instrumen pengumpulan data melalui angket, wawancara, observasi dan sebagainya. ${ }^{15}$ Informan pada penelitian ini adalah:

a. Siswa yang diambil adalah siswa kelas I dan Kelas II yang peneliti anggap lebih mewakili dalam menjawab pertanyaan-pertanyaan yang diberikan.

b. Guru yang dijadikan subjek penelitian ini adalah guru yang mengajar di kelas I dan II.

c. Kepala sekolah sebagai penanggung jawab keseluruhan proses pembelajaran di sekolah.

Adapun instrumen yang dijadikan dalam pengumpulan data dalam penelitian ini adalah sebagai berikut:

a. Observasi yaitu melaksanakan pengamatan langsung terhadap proses pembelajaran yang dikakukan guru dalam metode bercerita denagan buku cerita bergambar Islami

b. Wawancara yaitu dengan siswa, guru dan kepala sekolah, SDIT Bunayya Padangsidimpuan.

Analisis data yang dilaksanakan dengan menggunakan analisis deskriptif. Variabel deskriptif adalah analisis yang tidak menguji hipotesis tertentu, tetapi menggambarkan apa adanya tentang suatu variabel gejala. Semua data yang dihimpun dan disampaikan menggunakan metode induktif.

Untuk lebih jelasnya langkah-langkah yang dilakukan dalam analisis data sebagai berikut:

a. Editing data, yaitu menyusun redaksi data menjadi kalimat yang sistematis

b. Reduksi data memeriksa kelengkapan data untuk mencari data yang masih kurang dan mengesampingkan data yang relevan

c. Penarikan kesimpulan yaitu menerangkan uraian-uraian data dalam beberapa kalimat yang mengandung suatu pengertian secara singkat dan padat.

Data yang dipeorleh akan dilakukan pengujian keabsahannya dengan perpanjangan keikutsertaan akan banyak mempelajari "kebudayaan" dapat menguji ketidakbenaran informasi yang diperkenalkan oleh distori, baik yang berasal dari diri sendiri maupun dari responden, dan membangun kepercayaan subjek. Dengan demikian, penting sekali perpanjangan keikutsertaan itu guna berorientasi dengan situasi, juga guna memastikan apakah konteks itu dipahami dan dihayati. Cara yang dilakukan berikutnya adalah ketekunan pengamatan maksudnya untuk menemukan ciri-ciri dan unsur-unsur dalam situasi yang sangat relevan dengan persoalan atau isu yang sedang dicari dan kemudian memusatkan diri pada hal-hal tersebut secara rinci, maka ketekunan pengamatan menyediakan kedalaman. Terakhir, triangulasi sebagai teknik pemeriksaan yang memanfaatkan pengguna sumber, yaitu: ${ }^{16}$ (1) Membandingkan data hasil pengamatan

\footnotetext{
${ }^{15}$ Sugioono, Memahami Penelitian Kualitatif (Bandung: Alfabeta, 2007), hlm.3

${ }^{16}$ Lexi j.Moleong,Op.Cit., hlm. 178
} 
dengan data hasil wawancara, (2) membandingkan apa yang dikatakan orang depan umum dengan apa yang dikatakan secara pribadi, (3) Membandingkan apa yang dikatakan orangorang tentang situasi penelitian dengan apa yang dikatakan sepanjang waktu, (4) Membandingkan keadaan dan persfektif seseorang dengan berbagai pendapat dan pandangan orang seperti rakyat biasa, (5) membandingkan hasil wawancara dengan isi suatu dokumen yang berkaitan.

\section{HASIL PENELITIAN DAN PEMBAHASAN}

\section{Temuan}

Proses Pembelajaran Menggunakan Metode Bercerita Bergambar Berbasis Islam Dalam Membina Akhlak Siswa SDIT Bunayya Padangsidimpuan

Dalam melaksanakan pembelajaran di SDIT Bunayya tidak hanya di kelas, di mana, kapan, pada siapa dan dari siapa saja dapat berlangsung sepanjang hidup. Proses belajar tidak hanya terjadi pada anak tetapi pada guru, orangtua dan masyarakat yang terlibat dalam proses pembelajaran. Ada saatnya anak belajar dari guru dan orangtua tetapi ada saatnya guru dan orang tua belajar dari anak. Ada saatnya anak belajar dari lingkungan masyarakat sekitar (individu/lembaga) karena ilmu dan pengalaman tidak sepenuhnya ada pada guru dan orang tua, karenanya setiap bagian selalu membina kapasitas pribadi dan pengetahuannya. Alam yang sangat kaya menyediakan berbagai jenis benda yang bisa digunakan sebagai media dan bahan ajar yang diperlukan untuk mendukung efektivitas program pembelajaran. Media dan bahan ajar buatan digunakan dengan mengacu pada prinsip : reduce-reuse-recycle.

Proses metode bercerita yang dilakukan guru berdasarkan hasil wawancara peneliti dengan guru SDIT Bunayya misalnya pada pagi hari sebelum masuk ke kelas siswa selalu melaksanakan shalat dhuha, selesai shalat dhuha guru selalu memberikan cerita kisah-kisah Rasul dan siswa antusias dalam mendengarkan cerita kisah Rasul tersebut.

\section{Efektivitas Metode Pembelajaran SDIT Bunayya Padangsidimpuan}

Efektivitas berasal dari kata efektif yang artinya tepat, manjur, mujarab, tepat guna dan berhasil. ${ }^{17}$ Jadi, afektivitas adalah adanya kesesuaian antara orang yang melaksanakan tugas dengan sasaran yang dituju.

Di sekolah Dasar Islam Terpadu (SDIT) adalah bentuk satuan pendidikan dasar yang menyelenggarakan program pendidikan berdasarkan kurikulum nasional yang diperkaya dengan system pendekatan islami melalui pengintegrasian antara pendidikan agama dengan pendidikan umum, antara sekolah, orangtua dan masyarakat dengan mengoptimalkan ranah kognitif, afektif dan psikomotor.

\footnotetext{
${ }^{17}$ Adi Satrio, Kamus Ilmiah Populer Visi 7, (Jakarta: Sasongko, 2005), hlm. 132.
} 
Dalam memberikan pembelajaran pada umumnya guru SDIT Bunayya Padangsidimpuan menggunakan metode bercerita karena metode bercerita ini sangat efektif untuk membina akhlak siswa karena dengan bercerita siswa dapat memahami apa yang disampaikan oleh guru. Metode bercerita yang disampaikan guru selalu dikaitkan dengan nilai spritual siswa. Setiap kegiatan yang dilakukan anak dapat menyenangkan dengan dibuatnya metode bercerita. Pada semua bidang studi, misalnya pada pelajaran matematika dibuat soal cerita yang dapat dikaitkan dengan agama, contohnya, Vika membeli roti di pasar kemudian dia berbagi dengan temannya, jadi berapa lagi roti yang dimiliki Vika? Dalam konteks agama berbagi merupakan salah satu akhlak mulia karena berbagi dengan orang akan menanamkan sifat dermawan dan meniru sifat rasulullah. Selanjutnya dalam pelajaran bahasa Indonesia ada materi mengenai cerita dongeng, pihak sekolah lebih memilih cerita siroh tentang nabi dan para sahabat dengan harapan agar anak-anak lebih mencintai cerita berbentuk islami.

Sesuai dengan hasil wawancara dengan ibu Afrina yang mengatakan bahwa "Metode pembelajaran bercerita melalui gambar Islami dapat membina akhlak siswa SDIT Bunayya dengan cara guru membacakan sebuah kisah atau siroh mengenai nabi Muhammad lalu bu Afrina menceritakan kisah nabi Muhammad dan kemudian bapak nabi Muhammad dan nama ibu nabi Muhammad dengan antusias anak-anak mendengarkannya, kemudian setelah selesai siroh atau kisah diceritakan bu Afrina memberikan pertanyaan kepada siswa mengenai nama Bapak nabi Muhammad dan nama ibu nabi Muhammad dengan antusias anak-anak menjawab pertanyaan tersebut. ${ }^{18}$ Setelah cerita dibacakan oleh guru siswa mampu menceritakan kisah siroh tersebut kepada orangtuanya dan mengamalkannya dalam kehidupan sehari-hari sesuai dengan wawancara peneliti dengan guru kelas IB ${ }^{19}$ Proses pembelajaran bercerita lebih mudah dipahami oleh siswa, terbukti ketika shalat dhuha kebiasaan bercerita habis shalat duha, siswa meminta bercerita, ketika ada hal-hal yang ingin diubah dikaitkan dengan cerita bukan dengan menggurui, bukan dengan ngajar tapi dengan cerita siswa lebih bisa mengkhayalkan"

Selain menggunakan media kaset mengenai siroh dan kisah-kisah keteladan nabi, pihak sekolah juga menyediakan cerita kartun yang bergambar islami tentang kisah para nabi dan sahabat. Di perpustakaan juga tersedia beberapa buku-buku cerita bergambar dengan harapan akhlak siswa dapat meningkat dan dapat membangkitkan semangat siswa baik dalam melihat gambarnya maupun dengan ceritanya. Sesuai dengan wawancara yang disampaikan siswa kelas I "saya senang mendengarkan cerita yang disampaikan oleh Ibu Aisyah karena selain mendengarkan kami juga menonton

\footnotetext{
${ }^{18}$ Bulletin Edisi II Desember 2014

${ }^{19}$ Siti Aisyah siregar Guru Bidang kelas Kelas IB, wawancara pada Tanggal 15 September 2015
} 
kisah siroh yang setiap hari berlainan isi ceritanya. yang disampaikan ibu, disela-sela bercerita bu Aisyah juga memberikan nasehat agar menjadi anak yang berakhlak" 20

Setiap selesai bercerita guru menyampaikan pujian dan terima kasih kepada siswa dan menghendaki untuk berkisah pada waktu lain yang ditentukan selanjutnya. Apabila hubungan berkisah tersebut ada hubungannya dengan pemberian penilaian, maka untuk mengukur tingkat pemahaman anak siswa mengajukan beberapa pertanyaan terhadap bahan kisah yang telah disajikan tersebut.

Selain metode bercerita metode eksperimen juga dipakai untuk membina akhlak siswa dengan cara siswa langsung praktek ke lapangan dan langsung menguji coba apa yang dipelajarinya. Sesuai dengan hasil wawancara peneliti dengan ibu Afrina Misalnya, guru menjelaskan tentang pelajaran sains mengenai perkembangbiakan pada tumbuhan yang terjadi secara vegetatif buatan, salah satu cara perkembangbiakan vegetatif buatan ini dengan mencangkok tanaman berupa sawo. Siswa dibagi dalam empat kelompok untuk melakukan kegiatan mengkerat batang dan mengikis kambiumnya kemudian getahnya dikeringkan dan harus menunggu 2 sampai 5 hari untuk melakukan kegiatan berikutnya kemudian beberapa hari selanjutnya siswa membungkus batang yang sudah dikerat dengan tanah yang sudah dicampur humus terlebih dahulu dengan cara plastik yang sudah dilobang-lobangi/ sabut kelapa diikatkan ke pangkal rantingnya, diikat dan dimasukkan tanah yang sudah bercampur tanah. Sesekali hasil bungkusan tanah tersebut disiram. Kemudian selanjutnya metode eksperimen selesai dilakukan para siswa dan selanjutnya menunggu hasil eksperimen tersebut.

Selain dari metode eksperimen yang disampaikan di atas dalam matematika juga siswa menggunakan metode eksperimen sesuai dengan wawancara peneliti dengan bu Aisyah Siswa mempelajari bilangan operasi penjumlahan dan pengurangan dengan menggunakan sempoa siswa berbagi dan bersedekah dengan menggunakan sempoa dengan eksperimen tersebut siswa mempelajari sendiri mengenai penjumlahan dan pengurangan Contohnya $2+5$ siswa menggeser dua biji dari dereten biji disampingnya kemudian menggeser 5 lagi sehingga jumlahnya mencapai 7 dengan arti tanpa penjelasan dari guru siswa dapat menemukan sendiri jawaban yang ada pada alat sempoa tersebut.

Penggunaan teknik ini mempunyai tujuan agar siswa mampu mencari dan menemukan sendiri berbagai jawaban atau persoalan-persoalan yang dihadapinya dengan mengadakan percobaan sendiri. Juga siswa dapat terlatih dalam cara berfikir yang ilmiah. Dengan eksperimn siswa menemukan bukti kebenaran dari teori sesuatu yang sedang dipelajarinya.

Metode eksperimen yang dilakukan oleh guru dan siswa tersebut selalu dikaitkan dengan nilai-nilai agama.

\footnotetext{
${ }^{20}$ Nurul, Siswa kelas IB, Wawancara 15 September 2015
} 
Kemudian metode bercerita yang dilakukan oleh guru misalnya pada pelajaran Sains materi mengenai 4 sehat 5 sempurna guru mempersiapkan gambar dan menceritakan kepada siswa apa manfaat dari makanan 4 sehat lima sempurna. Jika kita tidak menkonsumsi makanan sehat maka tubuh tidak kuat sesuai dengan yang dianjurkan rasulullah, Allah lebih mencintai muslim yang kuat daripada muslim yang lemah dikaitkan dgn kisah rasulullah. Selanjutnya pada mata pelajaran sains mengenai lingkungan guru membawa siswa ke tempat wisata seperti Simarsayang siswa dikenalkan dengan alam ciptaan Allah dan alam buatan manusia kemudian siswa menyimpulkan pelajaran yang disampaikan oleh guru. Dari kunjungan wisata tersebut guru menyampaikan bahwa alam ciptaan Allah sangat luas maka kita sebagai ummatnya wajib bersyukur dan menyembah kepada-Nya.

\section{Kendala yang Dihadapi Guru dalam Membina Akhlak Siswa di SDIT Bunayya}

Proses pembelajaran merupakan hal yang paling menyenangkan bagi siswa yang menyukai dan haus akan ilmu pengetahuan dan sebaliknya, merupakan hal yang paling membosankan bagi siswa yang tidak peduli dan tidak menginginkan ilmu pengetahuan. Dalam proses pembelajaran tidak bisa dipungkkiri akan terjadi hal-hal yang diluar kehendak seorang guru.

Dalam hal ini walaupun pada umumnya siswa di SDIT Bunayya sudah memiliki akhlak mulia namun, masih ada beberapa siswa yang belum memiliki akhlak yang mulia karena pengaruh lingkungan dan didikan orang tua. Sebagaimana wawancara peneliti dengan salah seorang guru di SDIT Bunayya beberapa siswa yang belum baik akhlaknya, bisa saja pengaruh dari faktor lingkungan, mungkin di rumah dan lingkungan tidak bersambut antara yang diajarkan di sekolah ${ }^{21}$. Dengan lingkungan yang tidak baik misalnya siswa akan terikut dengan lingkungannya.

Sebagaimana menurut paham empirisme yang dipelopori oleh John Locke (16321704) yang mengatakan bahwa anak diumpamakan seperti meja lilin atau kertas putih dalam hal ini terserah kepada penulis, tulisan ataua goresan apa dan bagaimana yang digoreskan di atas meja atau dikertas putih tersebut. Demikian pula dengan anak, terserah kepada pendidik atau pengaruh lingkungan, hendak kemana dan akan dijadikan apa anak tersebut terserah kepada si pendidik. Paham ini memandang bahwa pengaruh lingkungan atau pendidikan itulah yang menentukan hidup manusia. Sedangkan pengaruh internal yang berupa kemampuan dasar, bakat, dan keturunan tidak berdaya sama sekali.

Kemudian menurut pengakuan bapak Mulyono kendala yang dihadapi dalam proses pembelajaran kurangnya pemahaman orangtua dalam mendidik anak. Orangtua menyerahkan anaknya ke sekolah sepenuhnya begitu anaknya pulang ke rumah tidak

${ }^{21}$ Masna, Guru Kelas IIB, wawancara tanggal 15 November 2015 
ada belajar sama sekali.22 Dalam hal ini diketahui bersama bahwa dalam mendidik anak itu harus ada kerja sama yang baik antara orang tua, dan pihak sekolah agar dapat membina akhlak siswa.

Sebagai orang tua terkadang dalam memberikan perhatian kepada anak itu berlebihan. Misalnya Si anak meminta sesuatu yang belum termasuk pada kebutuhannya, orang tua akan mengabulkan permintaan tersebut tanpa mempertimbangkan apa manfaat terhadap dari apa yang dimintanya, dengan alasan agar tidak mengganggu aktivitas kegiatan orang tua tersebut.

Sesuai dengan wawancara peneliti dengan pak Mulyono sebagian orang tua terlalu memanjakan anak di rumah semua permintaannya selalu dituruti, sehingga di sekolah ada kebutuhannya yang tidak terpenuhi kadang bukan niat mencuri tapi siswa tersebut menjahili kawannya atau adik kelasnya.

Dari hasil wawancara tersebut dapat disimpulkan bahwa kendala yang dihadapi guru pada umumnya kurangnya perhatian orangtua terhadap pendidikan di rumah. Walaupun pihak sekolah sudah berupaya dalam membina akhlak siswa akan tetapi orang tua juga harus mendidik anak di rumah agar sesuai dengan apa yang diterapkan di sekolah.

Kemudian dari segi sarana dan prasarana di SDIT Bunayya masih dalam tahap proses pembangunan, misalnya penggunaan infokus guru masih secara bergiliran dalam memakainya, jaringan internet juga masih terbatas ${ }^{23}$.

Selain dari kendala di atas, dari pihak guru juga terdapat kendala sesuai dengan hasil wawancara dengan pak Mulyono kegiatan guru lebih banyak di rumah dengan keluarganya, sehingga guru tidak mengumpulkan RPP, dari sekolah udah ada indikator, jadi tidak ada materi yang mengambang.

Untuk mengatasi kendala-kendala di SDIT Bunayya Padangsidimpuan guru memberikan sanksi jika siswa melakukan kesalahan misalnya berkata kasar terhadap kawannya atau kepada guru di sekolah. Sanksi yang diberikan oleh pihak sekolah hanya berupa sanksi untuk mendidik anak agar akhlaknya dapat berubah menjadi baik. Salah satu pengakuan guru sanksi itu terdapat 40 poin kesalahan, jika kesalahan tersebut sudah mencapai 40 poin maka siswa tersebut tidak diperbolehkan masuk sekolah dalam beberapa hari. Sanksi yang diberikan kepada siswa tersebut pada hakikatnya merupakan suatu pengajaran kepada orangtua siswa agar orangtua lebih memperhatikan tingkah laku anak tersebut.

\section{PENUTUP}

Berdasarkan pembahasan hasil penelitian ini, maka dapat disimpulkan sebagai berikut:

\footnotetext{
${ }^{22}$ Mulyono, Guru Kelas IB, Wawancara tanggal 06 November 2015

${ }^{23}$ Ibid.
} 
1. Proses pembelajaran menggunakan metode bercerita dengan buku cerita bergambar berbasis Islam dalam membina akhlak siswa SDIT Bunayya Padangsidimpuan. Dilaksanakan dengan metode bercerita Selain dari metode bercerita guru juga menggunakan metode kisah, keteladanan, ekspremen dan fokus. Setiap metode yang digunakan oleh guru selalu dikaitkan dengan penanaman nilai-nilai agama dengan tujuan agar dapat membina akhlak siswa.

2. Berdasarkan keterangan yang diperoleh dari kepala sekolah dan guru-guru SDIT Bunayya Padangsidimpuan ternyata dengan menggunakan metode bercerita dapat membina akhlak siswa karena dengan bercerita siswa dapat memahami apa yang disampaikan oleh guru.

3. Kendala-kendala yang dihadapi guru dalam membina akhlak siswa di SDIT Bunayya diantaranya:
a. Kurangnya perhatian orangtua
b. Kurangnya sarana dan prasarana karena SDIT Bunayya masih dalam tahap pembangunan.
c. Orangtua mempercayakan pendidikan siswa sepenuhnya kepada pihak sekolah
d. Orangtua terlalu memanjakan anak 
126 Tazkir Vol. 02 No. 1 Januari - Juni 2016

\section{DAFTAR RUJUKAN}

Abu Ahmadi, Dasar-dasar Pendidikan Agama Islam, Jakarta: Bumi Aksara, 2008

Arief Armai, Pengantar Ilmu dan Metodologi Pendidikan Islam, Jakarta: Ciputat Pers,2002

Bahri Syaiful, Djamarah, Guru dan Anak Didik dalam Interaksi Edukatif, Jakarta. PT. Asdi Mahasatya, 2005

Departemen Pendidikan Nasional, Undang-Undang Sistem Pendidikan Nasional Nomor20 Tahun 2003, Jakarta: Departemen Pendidikan Nasional, 2003

Departeman Pendidikan Nasional, Kamus Besar Bahasa Indonesia, Jakarta: Depdiknas, 2011

Depdiknas, Undang-undang tentang Perencanaan Pembangunan Nasional No.25, tahun 2004, Jakarta: Depdiknas, 2004

Istiqomah Santi, Upaya Meningkatkan Hasil Pembelajaran Pendidikan Agama Islam tentang Akhlak Melalui Metode Bercerita. Skripsi: STAIN Salatiga: 2013

Mohammad Nor Ichwan, Strategi Pembelajaran Agama Islam Berbasis P.A.I.K.E.M. Rasail, Semarang: 2008.

Moleong Lexi ., Metodologi Penelitian Kualitatif , Bandung: Remaja Rosda Karya, 2004

Moeslichatun, Metode Pengajaran di Taman Kanak-Kanak, Jakarta: Rineka Cipta, 1999

Nata Abudin, Akhlak Tasawuf, Jakarta: PT. Raja Grafindo Persada, 2006

Rahman Hibana S, Konsep Dasar Pendidikan Anak Usia Dini. Jakarta: Gramedia Utami Munandar 2002

Satrio Adi, Kamus Ilmiah Populer Visi 7, Jakarta: Sasongko, 2005

Suharso dan Retnoningsih Ana, Kamus Besar Bahasa Indonesia, Semarang: WidyaKarya, 2009

Sugioono, Memahami Penelitian Kualitatif Bandung: Alfabeta, 2007

Syafaruddin, dkk, Ilmu Pendidikan Islam Melejitkan Potensi Budaya Umat, Jakarta Selatan: Hijri Pustaka Utama, 2006

Tadkiroatun Musfiroh, Memilih, Menyusun, dan Menyajikan Cerita untuk Anak Usia Dini. Yogyakarta: Tiara Wacana, 2008

Wehr Hans, A Dictionary of Modern Written Arabic, London: Macdonald \& Evans Ltd., 197 Ali al-Khuli, Muhammad Dictionary of Education: English Arabic, Bairut-Libanon: Dar al'Ilm Li al-Malayin, 1981 